\title{
PROGRESIVISME: TITIK TEMU KEABSAHAN UU PESANTREN NOMOR 18 TAHUN 2019
}

\author{
Rz. Ricky Satria Wiranata \\ Program Studi Manajemen Dakwah \\ Sekolah Tinggi Agama Islam Terpadu Yogyakarta \\ rickysatriawiranata@gmail.com
}

\begin{abstract}
Abstrak
Pro kontra rancangan UU Pesantren dan Pendidikan Keagamaan berakhir dengan disahkan UU Pesantren pada bulan Oktober Tahun 2019. Sebagai konsekuensi, ada enam poin utama dalam UU ini yaitu regulasi, dana abadi, Kyai berpendidikan, manajerial, kurikulum dan mutu. Butir lain mengatakan bahwa Pesantren harus dirancang dan dilaksanakan dengan sebaik-baiknya berdasarkan nilai-nilai ketuhanan, kemandirian, profesional, akuntabilitas dan keberlanjutan. Semua butir dalam UU Pesantren mendukung adanya perubahan untuk mewujudkan sistem Pendidikan Pesantren yang maju dan modern tanpa menghilangkan kekhasan dan keunikannya. Berkaitan dengan persoalan tersebut terdapat salah satu aliran filsafat yang mendukung adanya perubahan dalam pelaksanaan Pendidikan. Aliran filsafat yang dimaksud adalah progresivisme. Progresivisme muncul untuk merespon praktik stagnasi dalam Pendidikan. Progresivisme menghendaki adanya perubahan Pendidikan yang lebih maju. Aliran Progresivisme mengutamakan Pendidikan berbasis pada anak, guru sebagai fasilitator dan pembimbing. Aliran ini hadir untuk membunuh sikap otoritarianisme dalam Pendidikan non demokratis. Penelitian ini adalah kualitatif, pendekatan yang digunakan dalam penelitian ini adalah filosofis, sumber primer dalam penelitin ini adalah Undang-undang Pesantren Tahun 2019.
\end{abstract}

Kata kunci : Filsafat, Progresivisme, UU Pesantren

\section{Abstract}

The draft law on Pesantren and Religious Education ended with the passed the Pesantren law in October 2019. As a consequence, there are six main points in this law, namely regulations, fund, Kyai, education, managerial, curriculum and quality. Another point said that Islamic boarding schools must be designed and implemented as well as possible based on the values of God, Independence, 
Rz. Ricky Satria Wiranata : Progresivisme: Titik Temu Keabsahan UU Pesantren Nomor 18 Tahun 2019

Professional, Accountability and Sustainability. All items in the Pesantren Law support changes to realize an advanced and modern Pesantren education system without losing its uniqueness and uniqueness. Related to this problem, there is one philosophical that supports changes in the implementation of education. Philosophical flow in question is progressivism. Progressivism appears to respond to the practice of stagnation in education. Progressivism requires changes in education that are more advanced. The Progressivism school prioritizes education based on children, teachers as facilitators and mentors. This flow exists to kill the attitude of authoritarianism in non-democratic education. This research is qualitative, the approach used in this research is philosophical, the primary source in this research is the Pesantren Law 2019.

\section{Keywords : Philosophy, Progressivism, UU Pesantren}

\section{A. PENDAHULUAN}

Secara historis, Pesantren adalah lembaga yang bergerak dalam bidang Pendidikan dan Dakwah Islam. Peran Pesantren dalam Pendidikan Nasional diakui keberadannya baik secara historis maupun yuridis. Salah satu peran Pesantren adalah menumbuhkan nilai-nilai akhlaq, cinta tanah air dan spirit menyebarluaskan ajaran rahmatan lilalamin. Dalam undangundang Pesantren yang disahkan pada tanggal 16 Oktober 2019 menunjukkan bahwa Negara hadir untuk mendorong Pesantren lebih progresive sehingga dapat mengambil bagian dalam memajukan berbagai aspek seperti ekonomi, Pendidikan, sosial kemasyarakatan, Agama dan lainnya di Indonesia.

Penyelengaraan Pesantren dalam UU Pesantren bertujuan untuk pertama: membentuk individu yang memahami dan mengamalkan nilai-nilai ajaran agamanya dan/atau menjadi ahli ilmu agama yang beriman, bertakwa, berakhlak mulia, berilmu, mandiri, ta'awun, tawazun, dan tawasut. Kedua mendorong terbentuknya pemahaman keberagamaan yang 
moderat, cinta tanah air, terwujud kerukunan hidup umat beragama, serta terbentuk watak peradaban bangsa yang mencerdaskan, bermartabat, dan berkemajuan. Ketiga: ikut serta dalam meningkatkan kualitas hidup masyarakat yang berdaya dalam memenuhi kebutuhan Pendidikan warga negara maupun kesejahteraan sosial masyarakat pada umumnya. ${ }^{61}$

Mengingat pentingnya Pesantren sebagai fondasi karakter bangsa, maka Pesantren harus dirancang dan dilaksanakan dengan sebaik-baiknya berdasarkan nilai-nilai perubahan, kemajuan dan moderninisasi. Sehingga Pesantren harus memperhatikan berbagai aspek seperti kurikulum, manajemen, sarana prasarana, SDM dan lain sebagainya. Selain kemandirian Pesantren, Negara juga harus hadir dalam mewujudkan Pesantren yang berdaya saing. Sehingga problem diskriminasi regulasi, diskriminasi anggaran, diskriminasi manajerial dan diskriminasi mutu tidak lagi terjadi dalam sistem Pendidikan Pesantren.

Berkaitan dengan persoalan tersebut, terdapat salah satu aliran dalam Filsafat Pendidikan yang mendukung adanya perubahan dalam pelaksananaan Pendidikan. Aliran filsafat yang dimaksud adalah progresivisme. Aliran ini merupakan sebuah gerakan yang menentang pelaksanaan Pendidikan secara tradisional seperti halnya aliran esensialisme dan perennialisme. Aliran progresivisme mendukung adanya pelaksanaan Pendidikan yang dipusatkan pada peserta didik dan mengembangkan berbagai kemampuannya sebagai bekal menghadapi kehidupkan sosial di lingkungannya.62 Filsafat 2019

61 Lihat pasal 3 Undang-undangg tentang Pesantren nomor 18 tahun

62 M. Fadhillah, Aliran Progresifisme dalam Pendidikan di Indoensia, Jurnal Dimensi: Vol. 5, No. 1. 2017 
Rz. Ricky Satria Wiranata : Progresivisme: Titik Temu Keabsahan UU Pesantren Nomor 18 Tahun 2019

progresivisme menaruh kepercayaan terhadap kekuatan alamiah manusia, yakni kekuatan yang diwarisi manusia sejak lahir. Progresivisme menjelaskan bahwa manusia sejak lahir telah membawa bakat, kemampuan atau potensi dasar, terutama daya akalnya, sehingga manusia akan dapat mengatasi segala problematika dalam kehidupannya. 63

\section{B. KERANGKA BERFIKIR}

Dalam memperjelas hubungan antara teori yang dibangun dan objek primer dalam penelitin ini, maka peneliti menawarkan asumsi berfikir sebagai berikut:

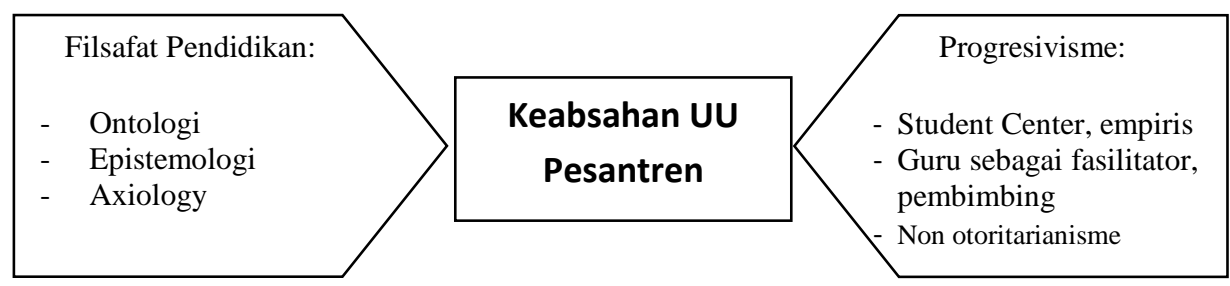

Gambar 1. Kerangka berfikir

\section{PEMBahasan}

1. Kajian Ontologi

Pendidikan adalah proses panjang dalam membentuk kepribadian yang sempurna. Pendidikan adalah kebutuhan primer seluruh manusia yang hidup. Manusia yang terdidik memiliki kemampuan untuk merespon kehidupan dengan akal yang sehat dan pengalaman yang tidak keliru. Pendidikan harus mencetak pribadi-pribadi yang sempurna, Pendidikan dalam arti menyerahkan seluruh aktifitas dalam hidupnya untuk baik dan membaikkan. Namun, kebaikan saja tidak cukup, Pendidikan juga harus mencetak pribadi

${ }^{63}$ Ibid. 
yang benar dalam arti menyerahkan seluruh aktifitas dalam hidupnya untuk benar dan membenarkan yang benar dan menyalahkan yang salah, baik dari perkataan maupun perbuatannya.

Setiap warga Negara memiliki hak untuk mendapatkan Pendidikan dan dijamin konstitusi yaitu UUD 1945 Pasal 31 tentang Pendidikan dan Kebudayaan. Seluruh warga Negara berhak dan wajib mengikuti Pendidikan Dasar dan Pemerintah wajib mendanainnya. Tujuannya adalah meningkatkan keimanan dan ketakwaan serta akhlak mulia dan mencerdasakan kehidupan bangsa. Melihat dari termonologi yang dipakai maka hakikatnya Pendidikan di Pesantren selama ini terbukti telah mampu melaksanakannya. Oleh sebab itu, seluruh stakeholder harus bahu-membahu dalam mendorong dan mendukung Pesantren untuk maju dan berkembang layaknya Pendidikan umum lainnya yang diselenggarakan oleh Pemerintah.

Sejarah panjang Pendidikan Pesantren di Indonesia telah ada jauh sebelum Indonesia merdeka. Disaat seluruh penjuru Nusantara dijajah selama 350 Tahun oleh Hindia Belanda dan 3,5 Tahun oleh Jepang namun tidak membuat Pendidikan Pesantren ditinggalkan oleh Umat Islam, justru semakin hari semakin maju dan berkembang. Dengan semangat Tauhid, nasionalis dan cinta tanah air, Pendidikan Pesantren terus maju dan mengalami kemajuan diatas dinamika politik dan payung keterjajahan yang dialaminya hingga Indonesia memperoleh kemerdekan pada Tahun 1945. Peran Pesantren semakin menunjukkan eksistensinya ketika musuh-musuh Indonesia tidak tinggal diam bahkan berusaha untuk merebut dan menjajah kembali Indonesia. 
Rz. Ricky Satria Wiranata : Progresivisme: Titik Temu Keabsahan UU Pesantren Nomor 18 Tahun 2019

Sehingga, pada bulan Oktober 1945 para ulama jawa memproklamasikan perang Jihad Fisabilah terhadap Belanda dan sekutunya. Hal ini memberikan signal dan kepastian hukum bagi masyarakat Indonesaia khususnya Islam untuk mempertahankan kemerdekaan Indonesia dengan segenap tumpah darah. Sehingga resolusi Jihad Ini menjadi salah satu tanda sejarah bahwa Pesantren telah mengambil peran bagi kemerdekaan Republik Indonesia.

Paska kemerdekaan dan kestabilan politik telah dimiliki Indonesia. Pesantren hadir menjalankan sila pertama dalam butir Pancasila yaitu Ketuhanan Yang Maha Esa. Tugas ini sangat berat karena memastikan seluruh komponen Pesantren dan masyarakat luas menerapkan nilainilai Ketuhanan. Misi Pendidikan dan dakwah Islam dilakukan secara mandiri dan dengan keikhlasan oleh tokohtokoh Pesantren berdakwah hingga sampai pelosok-pelosok negeri, tujuannya tidak lain adalah menjalankan sila pertama dalam norma pancasila. Hal ini berbeda dengan Pendidikan berbasis sekuler yang dilaksanakan pemerintah, target yang digapai adalah aspek rasionalitas berbasis empiris saja, sehingga tugas Pendidikan hanya terbatas pada transfer of knowlage saja sedangkan Pendidikan Pesantren dan agama memiliki tiga target yang harus selaras antara hati, akal, dan perbuatan.

Pesantren sebagai lembaga agama bertujuan untuk membenarkan akhlaq. Argumentasi ini tentu memiliki dasar yang kuat mengingat praktik degradasi akhlaq dikalangan masyarakat saat ini kerap menghiasi layar televisi. Sebut saja kasus pimpinan partai politik yang diciduk oleh KPK, kasus murid membacok gurunya sendiri hingga tewas, hingga kasus 
guru mengaji yang mencabuli santrinya. Semua masalahmasalah sosial diatas tidak lain karena kurangnya internalisasi nilai-nilai akhlaq dalam masing-masing individu masyarakat. Pendidikan selama ini masih berorientasi kepada kognisi saja belum menjadi sebuah karakter yang melekat dalam individu masing-masing masyarakat. Berbeda dengan Pesantren, Pendidikan yang berciri khas pondok (asrama) ini melaksanakan Pendidikan integral selama 24 Jam. Kyai dijadikan model (uswatun hasanah) bagi seluruh santri, penanaman nilai-nilai akhlaq menjadi visi besar bagi Pesantren. Proses pembiasaan terbimbing oleh dewan ustadz dan terawasi selama 24 jam. Hal inilah yang menjadi ciri khas dan hasil yang berbeda antara Pendidikan Pesantren dan Pendidikan lainnya.

Selain fokus terhadap meningkatkan akhlaq, Pesantren juga dibebankan untuk meningkatkan keimanan dan ketakwaan, cinta tanah air dan berkemajuan. Tugas tersebut jelas tercantum dalam pertimbangan pengesahan UU Pesantren tahun 2019. Selain itu, bukti sejarah bahwa Pesantren hadir dalam perjuangan kemerdekaan Indonesia dan berperan aktif dalam pergerakan kebangsaan dan pembangunan nasional. Sehingga wajar jika Pesantren dikatakan sebagai benteng pertahanan NKRI. Atas dasar tersebut, UU Pesantren merespon untuk melakukan upayaupaya kongkrit yang berorientasi untuk kemajuan Pesantren sehingga memiliki dampak konkrit dalam melahirkan santrisantri hebat yang berkarakter. ${ }^{64}$

Dalam pasal 3 UU Pesantren, menyebutkan bahwa tujuan penyelenggran Pesantren sangat kompleks. 
Rz. Ricky Satria Wiranata : Progresivisme: Titik Temu Keabsahan UU Pesantren Nomor 18 Tahun 2019

Setidaknya ada dua tujuan utama penyelenggara Pesantren yaitu tujuan agama dan tujuan bangsa. Tujuan agama yaitu membentuk individu yang memahami dan mengamalkan nilai-nilai ajaran agamanya dan/atau menjadi ahli ilmu agama yang beriman, bertakwa, berakhlak mulia, berilmu, mandiri, ta'awun, tawazun, dan tawasut. Sedangkan tujuan bangsa yaitu terbentuknya pemahaman keberagamaan yang moderat, cinta tanah air, terwujud kerukunan hidup umat beragama, serta terbentuk watak peradaban bangsa yang mencerdaskan, bermartabat, dan berkemajuan. Selain itu, Pesantren juga dituntuk untuk meningkatkan kualitas hidup masyarakat yang berdaya dalam memenuhi kebutuhan Pendidikan warga negara maupun kesejahteraan sosial masyarakat pada umumnya.

Tugas berat yang dibebankan kepada Pesantren dan Lembaga Keagamaan diatas menunjukan bahwa Negara harus hadir dalam Pendidikan Pesantren. Pesantren tidak dapat berdiri sendiri, apa lagi Negara tidak berpihak kepada Pesantren dengan kebijakan-kebjakan yang tidak menguntung Pesantren, kebijakan yang dibuat dengan mengkebiri dan reorientasi kepada kemajuan Pesantren. Pesantren harus didorong dari berbagai aspek baik SDM, mutu, fasilitas dan dana cukup. Negara harus dapat mendukung, membimbing, memfasilitasi dan memastikan kepastian hukum sehingga tidak terjadi lagi diskrimasi antara Pesantren dan lembaga Pendidikan umum yang diselenggaran pemerintah maupun non pemerintah.

Undang-undang Pesantren yang telah disahkan diharapkan mampu menjawab keseriusan Negara dalam merespon amanat UUD 1945 yaitu mencerdasakan 
kehidupan bangsa dan ikut melaksanakan ketertiban dunia. Selain itu, konstitusi kita menjamin setiap orang bebas memilih dan beribadah sesuai kepercayaannya masingmasing dan setiap orang bebas memilih Lembaga Pendidikan yang bertujuan untuk meningkatkan keimanan, ketakwaan dan akhlaq mulia.

2. Kajian Epistemologi

Munculnya keputusan Presiden nomor 22 tahun 2015 tentang hari santri menunjukkan komitmen pemerintah dalam mewujudkan Pesantren yang bermutu. Namun hal tersebut tidak cukup jika hari santri hanya dijadikan ritualitas dan peringakat atas kontribusi kaum santri dalam upaya kemerdekaan Indonesia. Setidaknya ada tiga pertimbangan presiden menjadikan tanggal 22 Oktober sebagai hari santri yaitu pertama bahwa Ulama dan kaum Santri memiliki perean besar dalam kemerdekaan Indonesia, kedua bahwa untuk mengenang, meneladani, dan melanjutkan peran ulama dan santri dalam membela dan mempertahankan Negara Kesatuan Republik Indonesia, ketiga bahwa peringatan hari Santri merujuk pada resolusi Jihad pada tanggal 2 Oktober 1945.

Berdasarkan keputusan presiden diatas dan diakuainya secara yuridis bahwa Pesantren sebagai bagian penting dalam menjaga Negara Kesatuan Republik Indonesia. Maka munculah Undang-undang Pesantren sebagai respon dari Kepres dan saran publik yang berkembang. Setidaknya ada lima problem epistemologi yang ingin diselesaikan oleh UU Pesantren yaitu problem regulasi, Dana Abadi, Manajamen, Kyai berPendidikan, Pembelajaran dan Mutu. 
Rz. Ricky Satria Wiranata : Progresivisme: Titik Temu Keabsahan UU Pesantren Nomor 18 Tahun 2019

a. Tentang Regulasi

Undang-undang No. 20 tahun 2003 tentang sistem Pendidikan nasional hanya membahas tentang Pendidikan secara formal. Ini menyisakan persoalan di mana Lembaga Pendidikan Keagamaan yang notabennya berada pada wilayah informal belum tersentuh. Kedudukan Lembaga Pendidikan Keagamaan dan Pesantren dapat dilihat dalam UU Sisdiknas No. 20 Tahun 2003 Pasal 30 ayat 4. Dalam ayat tersebut dijelaskan bahwa Pendidikan keagamaan berbentuk Pendidikan Diniyah, Pesantren, Pasraman, Pabhaja Samanera, dan bentuk lain yang sejenis. Kalau merujuk pada Pasal 26 UU Sisdiknas tersebut Pesantren kategori Pendidikan non formal. Dasar yuridis keberadaan Pesantren salaf tidak ditemukan dalam UU Sisdinas. Adapun Peraturan Pemerintah No.55 Tahun 2007 Pasal 14 menyebutkan Pesantren dapat menyelenggarakan satu atau berbagai satuan dan/atau program Pendidikan pada jalur formal, nonformal, dan informal. 65

Berdasarkan identifikasi masalah diatas, maka UU Pesantren merespon dengan menerbitkan 4 butir dalam pasal 23 UU Pesantren yang menjelaskan bahwa pertama Pesantren jalur Pendidikan nonformal dapat diselenggrakan secara berjenjang atau tidak berjenjang. Kedua Pesantren dapat mengeluarkan syahadah sebagai tanda kelulusan pada jenjang Pendidikan tertentu. Ketiga lulusan pada jenjang Pendidikan Pesantren diakui dengan Pendidikan formal lainnya setelah lulus ujian yang diselenggarakan oleh satuan Pendidikan yang terakreditasi

65 Naskah akademik, RUU tentang Pesantren dan Pendidikan Keagaman, Badan Legislasi, 2018 
ketentuan peraturan perundang-undangan. Keempat lulusan Pesantren yang memperoleh ijazah sederajat Pendidikan formal dapat melanjutkan ke jenjang berikutnya pada jenis Pendidikan lainnya. ${ }^{66}$ Konsekuansi dari UU Pesantren tersebut menjadi landasan yuridis bagi seluruh Pesantren di Indonesia untuk meningkatkan mutu tanpa terbentur dengan problem regulasi yang selama ini mengunci pergerakan Pesantren.

b. Tentang Dana Abadi

Pasal 31 ayat 4 UUD NRI 1945, bahwa Negara memprioritaskan anggaran Pendidikan sekurangkurangnya 20\% dari APBN serta dari APBD untuk memenuhi penyelenggaraan Pendidikan nasional. Sehingga penyebutan verbal numeral $20 \%$ anggaran Pendidikan harus dialokasikan secara merata kepada semua komponen subsistem Pendidikan, baik pada jenjang dan jenis Pendidikan yang berbeda, dalam keseluruhan sistem Pendidikan nasional, yang di dalamnya ada lembaga Pendidikan keagamaan. APBN 20\% harus menempatkan Pendidikan sebagai kultur investasi jangka panjang termasuk Pendidikan Agama di dalamnya Lembaga Pendidikan Keagamaan dan Pesantren. Kenyataan empirik muncul tidak setaranya pengalokasian APBN ataupun APBD untuk Pondok Pesantren. Disparitas anggaran yang cukup tinggi antara Lembaga Pendidikan umum dan Pondok Pesantren, berdampak dalam peningkatan mutu 
Rz. Ricky Satria Wiranata : Progresivisme: Titik Temu Keabsahan UU Pesantren Nomor 18

antara Lembaga Pendidikan yang sejenis, khususnya berkaitan dengan penyediaan sarana dan prasarana. 67

Problem tersebut kemudian direspon oleh UU Pesantren pasal 48 dan 49 yang berbunyi. Pertama Sumber pendanaan penyelenggraan Pesantren berasal dari masyarakat. Kedua pemerintah Pusat dan Pemerintah Daerah sesuai kewenangannya berkewajiban mengalokasikan pendanaan dalam penyelenggaraan Pesantren. Ketiga pendanaan penyelenggaraan Pesantren bersumber dari penyelenggara, masyarakat, dan sumber lain yang sah. Keempat Pemerintah menyediakan dan mengelola dana abadi Pesantren yang bersumber dan merupakan bagian dari dana abadi Pendidikan

c. Tentang Kyai BerPendidikan

UU No. 14 Tahun 2005 Tentang Guru dan Dosen mensyaratkan kenaikan tunjangan mengukur profesionalitas Guru dan Dosen yang sudah mendapatkan sertifikat profesi. Bahwa Guru wajib memiliki kualifikasi akademik, kompetensi, sertifikat pendidik, sehat jasmani dan rohani, serta memiliki kemampuan untuk mewujudkan tujuan Pendidikan nasional. Sertifikat profesi seakan-akan hanya bersifat formalitas belaka, tidak menyentuh substansinya. Oleh sebab itu, kriteria atau ukuran yang digunakan sebagai syarat guru mendapatkan sertifikat profesi belum cukup jika diterapkan bagi guru/ustadz yang mengajar di Lembaga Pendidikan dan Pesantren. Disamping itu pada tataran operasional mengenai Guru Agama yang ditempatkan di berbagai

67 Naskah akademik, RUU tentang Pesantren dan Pendidikan Keagaman, Badan Legislasi, 2018 
sekolah dibawah naungan Kemendikbud, namun dari segi tunjangan dan pembinaan tetap dalam naungan Kementerian Agama. 68

Untuk meningkatkan profesionalitas, kualifikasi dan sertifikasi para ustadz/ustadzah maka UU Pesantren merespon dengan mengeluarkan Pasal 9 yang berbunyi Kyai atau sebutan lain harus memiliki kompetensi ilmu agama yang dipersyaratkan merupakan lulusan Pesantren atau Pendidikan Tinggi Agama Islam dan atau memiliki kompetensi dalam bidang Ilmu Agama Islam. Sehingga jika Kyai dalam sebuah Pesantren bukan alumni Pesantren atau Pendidikan Tinggi Agama atau tidak memiliki kompetensi bidang Ilmu Agama Islam, maka kredibiltas sebuah Pesantren tersebut masih dalam tanda tanya. Hal ini beralasan karena Kyai merupakan figur, teladan, dan/atau pengasuh dalam penyelenggaraan Pesantren, selain itu UU ini mensyaratkan Pesantren agar memiliki pengelola, tenaga pendidik dan tenaga kependidikan yang diperlukan dengan kompetensi sesuai kebutuhan Pesantren.

d. Tentang Manajerial

Temuan lapangan bahwa lembaga Pendidikan berbasis masyarakat terutama Madrasah dan Pesantren yang secara manejerial masih butuh dukungan untuk ditingkatkan. Variable yang perlu mendapat perhatian yaitu fasilitasi untuk pengelolaan sumber daya organisasi Pesantren yaitu: SDM (kyai, ustadz, pembina, pengelola, santri), sarana/prasarana: Masjid, Ruang Kelas, Pondok,

68 Wawancara dinas Pendidikan Kota Suarabaya dalam Naskah akademik, RUU tentang Pesantren dan Pendidikan Keagaman, Badan Legislasi, 2018. 
Rz. Ricky Satria Wiranata : Progresivisme: Titik Temu Keabsahan UU Pesantren Nomor 18 Tahun 2019

sanitasi, akses informasi, kurikulum dan kesetaraan ijazah dan serta akses melanjutkan Pendidikan. Beberapa variable tersebut antara lain yang membutuhkan pengelolaan manajemen profesional guna mewujudkan Pesantren yang berkualitas. 69

Problem dan temuan Syamsudduha diatas mungkin terjawab dengan terbitanya Pasal 11 dalam UU Pesantren tentang Pondok atau asrama harus memperhatikan aspek daya tampung, kenyamanan, kebersihan, kesehatan, dan keamanan. Pasal 12 Pemerintah Pusat dan Pemerintah Daerah sesuai dengan kewenangannya dapat memfasilitasi Masjid atau Mushala Pesantren untuk memenuhi aspek daya tampung, kenyamanan, kebersihan, kesehatan, dan keamanan. Pasal 9 Kyai dipersyaratkan lulusan Pesantren/ perguruan tinggi Islam/ memiliki kompetensi agama yang mumpuni. Pendidikan dan pengelola Pesantren harus berkompeten sebagaimana tercantum dalam pasal. Pasal 19 Santri yang dinyatakan lulus dari berbagai jenis jenjang dapat melanjutkan kejenjang lebih tinggi baik sejenis atau tidak sejenis, selain itu santri tetap mendapat kesempatkan kerja. Atas dasar ini, santri tidak perlu khawatir tehadap masa depan mereka. Lulusan diniyah formal dapat melanjutkan dan mengembangakn bakatnya masing-masing.

e. Tentang Kurikulum

Selama ini praktik kurikulum di beberapa Pesantren belum memiliki struktur dan konsep yang sesuai standar Nasional khususnya bagi Pesantren yang berbasis salaf/

69 Syamsudduha dalam Naskah akademik, RUU tentang Pesantren dan Pendidikan Keagaman, Badan Legislasi, 2018 
tradisional. Selain itu, praktik Pendidikan Pesantren yang berbasis kitab kuning terkadang belum disusun secara sistematis dan integral. Selain itu kurikulum kitab kuning belum mengkontekstualisasikan dengan ilmu umum atau problem-problem kontemporer masyarakat. Sekalipun ini menjadi identitas Pesantren sebagai penyelenggara Pendidikan yang mempertahankan kesanadan keilmuan, namun problem-problem sosial yang ditemukan dilapangan membuat Pesantren harus merekontruksi sistem kurikulum yang telah berjalan.

Oleh sebab itu, UU Pesantren ini merespon dengan mengeluarkan peraturan melalui Pasal 10 tentang kajian kitab kuning atau dirasah islamiyyah sebagaimana harus dilaksanakan dengan pola Pendidikan yang disusun secara sistematis, terintegrasi, dan komprehensif dalam memadukan ilmu agama Islam dan ilmu umum. Selain itu, UU Pesantren menjelaskan bawah Kajian kitab kuning atau dirasah islamiyyah dapat dilaksanakan dengan menggunakan metode pengajian individual (sorogan), pengajian massal (bandongan), metode klasikal, terstruktur, dan berjenjang, dan/atau metode pembelajaran lain.

f. Tentang mutu

Kritikan yang dilontarkan oleh Zamakhsyari Dhofier tentang praktik Pesantren membuka paradigma baru tentang Pendidikan di Pesantren, Zamakhasyari mensinyalir bahwa kebanyakan kyai di Jawa beranggapan bahwa suatu Pesantren dapat diibaratkan sebagai suatu kerajaan kecil dimana Kyai merupakan sumber mutlak dari kekuasaan dan kewenangan (power and authority) 
Rz. Ricky Satria Wiranata : Progresivisme: Titik Temu Keabsahan UU Pesantren Nomor 18 Tahun 2019

dalam kehidupan dan lingkungan Pesantren. Hal ini menjadi logis jika maju mundurnya sebuah Pesantren tergantung bagaimana kebijakan kyainya sendiri. Manajemen, pengembangan SDM, dan berbagai hal lainnya menjadi domain Kyai, dan Kyai menjadi kompas Pesantren yang menunjukkan kemana arah Pesantren. ${ }^{70}$

Kritik-kritik yang berkembang dikalangan praktisi Pendidikan tersebut kemudian direspon oleh UU Pesantren pasal 25 tentang Sistem Penjaminan Mutu. Sistem penjaminan mutu Pesantren bertujuan untuk melindungi, mewujudkan, dan memajukan Pesantren. UU ini juga mengatur untuk membentuk Dewan Masyayikh yang dipimpin oleh Kyai, Dewan Masyayikh bertugas melaksanakan sistem penjaminan mutu internal Pendidikan Pesantren. Dewa Masyayikh bertugas menyusun kurikulum Pesantren, melaksanakan kegiatan pembelajaran, meningkatkan kompetensi dan profesionalitas, pendidik dan tenaga kependidikan, melaksanakan ujian untuk menentukan kelulusan Santri berdasarkan kriteria mutu yang telah ditetapkan, dan menyampaikan data Santri yang lulus kepada Majelis Masyayikh. Dalam tafsiran pasal 26 menyebutkan sistem penjaminan mutu Pendidikan Pesantren terdiri atas sistem penjaminan mutu internal dan sistem penjaminan mutu eksternal. Sistem tersebut mencakup penilaian Iembaga Pendidikan Pesantren berdasarkan kriteria mutu yang ditetapkan, rekognisi lulusan, rekognisi pendidik, dan tenaga kependidikan sebagai tenaga profesional, rekognisi

70 Fata Asyrofi Yahya, Problem Manajemen Pesantren, Sekolah, MADRASAH: Problem Mutu dan Kualitas Input-proses-output, Jurnal el-Tarbawi, Vol. VII, No. 1, 2015, hal. 107 
kesetaraan kualifikasi dan kompetensi pendidik dan tenaga kependidikan dengan Pendidikan formal melalui mekanisme rekognisi pembelajaran lampau, afirmasi dalam melindungi kekhasan Pendidikan Pesantren, serta fasilitasi dalam mengembangkan Pendidikan Pesantren.

\section{Kritik Axiologis}

Hasil penelusuran sejarah ditemukan sejumlah bukti kuat yang menunjukkan bahwa cikal bakal pendirian Pesantren pada awal ini terdapat di daerah-daerah sepanjang pantai utara Jawa, seperti Gresik, Surabaya, Tuban, Kudus, Lasem, dan Cirebon. Kota-kota tersebut pada waktu itu merupakan kota kosmopolitan yang menjadi jalur penghubung perdagangan dunia, sekaligus tempat persinggahan para pedagang dan muballigh Islam yang datang dari Jazirah Arab seperti Hadramaut, Persia, dan Irak. ${ }^{71}$ Mengenai sejarah berdirinya Pesantren pertama atau tertua di Indonesia terdapat perbedaan pendapat di kalangan peneliti, baik nama Pesantren maupun tahun berdirinya. Berdasarkan hasil pendataan yang dilakukan oleh Departemen Agama pada 1984-1985 diperoleh informasi bahwa Pesantren tertua di Indonesia adalah Pesantren Jan Tanpes II di Pamekasan Madura yang didirikan pada tahun 1762.72

Secara axiologis, Pesantren merupakan basis kultur di Indonesia. Pesantren merupakan Lembaga Pendidikan tertua di Indonesia, hingga saat ini model Pendidikan Pesantren masih bertahan di tengah-tengah modernisasi Pendidikan.

${ }^{71}$ Fatah Syukur, Dinamika Pesantren dan Madrasah (Cet. I; Yogyakarta: Pustaka Pelajar, 2002), hal. 248.

72 Departemen Agama RI., Nama dan Data Potensi Pondok-Pondok Pesantren Seluruh Indonesia (Jakarta: Depag RI., 1984/1985), hal. 668 
Rz. Ricky Satria Wiranata : Progresivisme: Titik Temu Keabsahan UU Pesantren Nomor 18 Tahun 2019

Sehingga hasil Pendidikan Pesantren tertanam dalam kebudayaan nusantara. Pendidika yang khas, unik dan berciri kemandirian menjadikan Pesantren masih menjadi pilih utama masyrakat untuk menitipkan anaknya menuntuk ilmu di Pesantren. Bahkan, Pesantren juga diminati oleh santri yang berasala dari luas Indonesia seperti Malaysia, Singapura dan Thailand.

Secara historis, Negara-negara sahabat seperti Malaysia, Singapura, Thailand dan seterusnya dahulu pernah belajar Pendidikan dan keagamaan di Indonesia kemudian mengembangkan dinegaranya masing-masing. Namun sekarang kita harus mengakui bahwa Pendidikan mereka sedikit lebih kedepan dengan Negara yang katanya "gurunya". Sedikit menggelitik, namun faktanya demikian. Hal tersebut terjadi karena beberapa asumsi seperi Pendidikan Pesentren justru hanya sebagai Lembaga Pendidikan saja, sehingga tidak memiliki andil lebih besar bagi existensi sebuah bangsa dimata dunia. Selain itu, kesetaraan, status formal dan dukungan dari berbagai pihak khususnya pemangku kebijakan belum dirasakan secara langsung. Pesantren dituntun untuk mandiri, Pesantren harus menghidupkan dan membiayai dirinya masing-masing. Sehingga ada beberapa Pesantren yang mengalami stagnasi, namun banyak juga yang dapat berkembang pesat.

Selain aspek historis, muncul problem globalisasi dan desakan teknologi seperti gadget dan media informatika sejenisnya. Tagline "Pesantren siap menghadapi tuntutan zaman" rasanya semakin jauh, manakala justru Pesantrenlah yang menjadi pionir melarang santrinya menggunakan gadget. Padahal gadget adalah bagian yang tidak dapat 
dipisahkan dalam kehidupan modern saat ini. Santri-santri tidak dibekali Pendidikan gadget sehingga wajah Pesantren mengalami stagnasi ilmu pengetahuan dan teknologi. Potret ini tentu tidak sejalan dengan agenda pembaharuan yang dicanangkan semenjak awal abad 17 di Mesir oleh Muhammad Abduh.

Namun, alasan Pesantren melarang santrinya menggunakan gadget juga memiliki alasan yang kuat. Problem sosial bagi kaum milenial tentu tidak dapat dianggap remeh. Jika kita perhatikan, pergesaran sosial etik kaum milenial memang banyak dipengaruhi oleh benda kecil yang selalu dibawanya kemanapun baik siang maupun malam yaitu gadget. Anak-anak sangat sulit dipisahkan dari dunia gadget, informasi yang diterima anakpun sangat susah difilter oleh orang tua dan Guru. Sehingga, problem ini menjadi permasalah tersendiri bagi dunia Pendidikan Islam, secara khusus Pesantren yang seperti terjebak dalam buah simalakama.73 Disisi lain ingin mengimbangi pengaruh teknologi, namun disisi lain ada permasalah sosial yang dipertaruhkan oleh Pesantren.

Dalam konteks kehidupan bermasyarakat, gadget membuat pemuda kehilangan jati diri, malas bergerak dan beraktifitas, tidak mampu membangun ketrampilan dan kemampuan sosial, mementingkan diri sendiri hingga mudahnya mengakses situs negatif adalah dampak langsung dari sebuah benda kecil bernama gadget yang tidak terlepaskan dari kehidupan anak muda saat ini. Yang menarik, munculnya gadget sangat mempengaruhi sosial

73 Buah simalakama adalah pribahasa Indonesia yang bermakna situasi kondisi yang serba salah. Sumber www.kamusperibahasa.com yang diakses pada 29 Oktober 2019 pukul 14.00 WIB. 
Rz. Ricky Satria Wiranata : Progresivisme: Titik Temu Keabsahan UU Pesantren Nomor 18 Tahun 2019

masyarakat di Indonesia. Jika dahulu kumandang adzan magrib menjadi tanda berhentinya seluruh aktifitas masyarakat. Kita akan menyaksikan orang tua dan anakanak muda berbondong-bondong untuk menunaikan sholat di masjid, riuh suara pengajian Al-Qur'ann di Masjid, Mushola dan Surau menghiasi kehidupan masyarakat dahulu. Namun, cerita tersebut nampaknya sedikit bergeser, hal tersebut dibuktikan dengan minimnya peran anak muda dalam kegiatan sosial karena diasyikkan oleh aktifitas gadget yang mereka genggam. Maka benar istilah bahwa gadget dapat mendekatkan yang jauh, dan menjauhkan yang dekat.

Selain aspek axiologis, muncul tuduhan-tundah tak mendasar kepada Pesantren tentang paham radikalisme dan terorisme. Hal tersebut justru membuat posisi Pesantren semakin terpukul, manakala pelakunya justru bukan santri namun mengatas namakan santri. Truth claim dan penggiring opini justru semakin liar melalui media-media mainstrim, surat kabar bahkan telivisi nasionalpun ikut meramaikan dan bermain dengan isu ini. Jika melihat buku sejarah, potret yang ditampilkan sangat jauh dari intrepatasi yang dibangun media, apa lagi media-media luar negeri yang berbasis kapitalis-komunis. Oleh sebab itu, UU Pesantren yang baru saja di ketuk palu, diharapkan menjadi peredam dan mengejawantahkan atas isu-isu miring tentang Pesantren. Sekalipun tuduhan tersebut benar, namun generalisasi seluh Pesantren adalah praktik yang salah dan keliru.

Menurut Thomas O'Dea, jika ditinjau dari aspek sosiologi ada dua peran lembaga-lembaga keagamaan seperti Pesantren yaitu: peran sebagai directive system dan defensive 
system. ${ }^{74}$ Pertama dalam peran yang pertama directive system, Agama ditempatkan sebagai referensi utama dalam proses perubahan. Dengan demikian, Agama akan dapat berfungsi sebagai supremasi moralitas yang memberikan landasan dan kekuatan etik-spiritual masyarakat ketika mereka berdialektika dalam proses perubahan. Kedua yaitu defensive system, Agama menjadi semacam kekuatan kehidupan yang semakin kompleks di tengah derasnya arus perubahan. Masyarakat yang berpegang pada nilai-nilai religius akan mempunyai kemampuan untuk mempertahankan diri dan tidak ada rasa kekhawatiran serta keragu-raguan dalam menghadapi tantangan kehidupan.

Kabar baiknya, Pesantren sebagai Lembaga Pendidikan Islam yang memiliki keunikan tersendiri, telah mengalami perkembangan yang sangat berarti ditengah ujian historis, globalisasi dan truth claim. Bahkan Pesantren merupakan bagian yang tidak terpisahkan dari sejarah pertumbuhan masyarakat Indonesia. Hal itu telah terbukti sejak kurun kerajaan Islam pertama di Aceh dalam abad-abad pertama Hijriah, kemudian dikurun Wali Songo sampai permulaan abad 20, hingga pada zaman kontemporer saat ini banyak para wali, ulama, ustadz, santri mengambil peran dalam pembangunan bangsa dihampir seluruh sektor-sektor strategis seperti Pendidikan, ekonomi, politik, sosial, keagamaan dan lain sebagainya. 75

74 Thomas O’Dea, Sosiology of Region, Terj., (Jakarta: Rajawali, 1987), hal. 132.

75 Marwan Saridjo, Sejarah Pondok Pesantren di Indonesia, (Jakarta, Dharma Bhakti, 1982), hal. 7 
Rz. Ricky Satria Wiranata : Progresivisme: Titik Temu Keabsahan UU Pesantren Nomor 18 Tahun 2019

\section{Paradigma Progresivisme Terhadap UU Pesantren}

Filsafat Progresivisme lahir sebagai pembaharu dalam bidang Pendidikan terutama sebagai lawan terhadap kebijakan-kebijakan konvensional yang diwarisi dari abad XIX. Pencetus Aliran filsafat progresivisme yang populer adalah Jhon Dewey. Aliran filsafat Progresivisme bermuara pada aliran filsafat pragmativisme yang diperkenalkan oleh William James (1842-1910) yang menitik beratkan pada manfaat praktis. Dalam banyak hal, Progresivisme identik dengan pragmativisme. Filsafat Progresivisme dipengaruhi oleh ide-ide filsafat pragmativisme yang telah memberikan konsep-konsep dasar dengan asas yang utama, bahwa manusia bisa survive menghadapi semua tantangan hidup, manusia harus pragmatis dalam memandang kehidupan. ${ }^{76}$

Berangkat dari kegelisah Jhon Dewey, progresisvisme berusaha menggapai pengaruh positif yang ada dalam perkembangan ilmu pengetahuan dan teknologi. Jhon Dwhey beranggapan bahwa segala sesuatu dalam dunia ini harus dikembalikan kepada fitrah manusia. Menurutnya manusia terbukti telah mampu menciptakan peradaban yang maju dari masa kemasa. semua fakta tersebut dipandang sebagai sebuh kemajuan sehingga aliran ini disebut sebagai progresivisme. Gagasan yang menarik dari progresivisme adalah tentang cara pandang kedepan. Progresivime menganggap semua yang ada dibelakang hanya catatancatatan yang berguna untuk dipelajari dan dapat diambil dalam konteks saat ini. Menurut Jhon Dewey manusia dianggap sebagai makhluk yang berkembang dan dinamis,

76 Ali dalam Mukh Nursikin, Aliran-aliran Filsafat Pendidikan dan Implementasinya dalam Pengembangan Kurikulum Pendidikan Islam, Jurnal Attarbiyah, Vol 1 No 2, 2016, hal. 311 
selain itu manusia memiliki kebebesan (freedom) untuk menentukan kemajuan manusia itu sendiri. ${ }^{77}$

Menurut Ornstein dalam Ricardo F. Nanuru ada empat prinsip pragmatisme yang ditawarkan dalam konteks Pendidikan yaitu: 78

a. Anak-anak dibiarkan bebas berkembang secara alami

b. Anak-anak didorong langsung pada pengalaman karena dianggap sebagai pendorong yang paling baik dalam pengajaran.

c. Guru harus menjadi seorang narasumber, pembimbing dan pengarah dalam aktivitas pembelajaran.

d. Sekolah Progresivisme seharusnya menjadi sebuah laboratorium bagi reformasi Pendidikan dan tempat untuk bereksperimen.

Berdasarkan teori progresivisme yang ditawarkan oleh Jhon Dewey dan prinsip-prinsip progresivisme yang dikembangkan Ornstein, maka terdapat relasi yang kuat antara teori progresivisme terhadap keabsahan UU Pesantren yang telah disahkan. Titik temu penelitian ini adalah spirit terhadap perubahan untuk mewujudkan sistem Pendidikan Pesantren yang maju dan modern tanpa menghilangkan kekhasan dan keunikannya. UU Pesantren dan aliran Progresivisme bergandengan untuk merespon praktik stagnasi dalam Pendidikan. UU Pesantren menghendaki adanya perubahan Pendidikan yang lebih maju sedangkan progresivisme mengusulkan Pendidikan berbasis pada Anak,

77 Ilun Mualifah, Progresivisme John Dewey dan Pendidikan Partisifatif Persfektif Pendidikan Islam, Jurnal Pendidikan Agama Islam, Vol 1. No. 1 Mei 2013, hal. 105

78 Ricardo F. Nanuru, Progresisvisme Pendidikan dan Relevansinya di Indonesaia, Jurnal Uniera, Vol. 2 No. 2, 2013, hal. 136 
Rz. Ricky Satria Wiranata : Progresivisme: Titik Temu Keabsahan UU Pesantren Nomor 18 Tahun 2019

Guru sebagai fasilitator agar Pendidikan lebih maju. Progresivisme menempuh cara dengan membunuh sikap otoritarianisme dalam Pendidikan sebagai upaya mewujudkan Manusia sesuai fitrahnya. Lebih lengkap dibawah ini peneliti mengkatagorisasikan dalam sebuah tabel sebagai berikut:

Tabel 1: Analisis progresivisme atas UU Pesantren

\begin{tabular}{|c|c|c|}
\hline TEORI & PRAKTIK LAMA79 & PROGRESIV \\
\hline  & 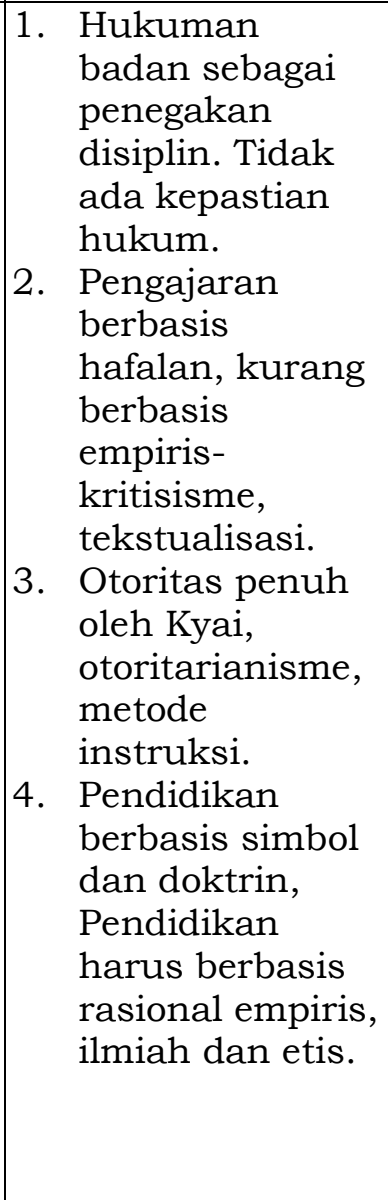 & $\begin{array}{l}\text { 1. Bahwa setiap anak } \\
\text { bebas memeluk agama, } \\
\text { ibadah, Pendidikan, } \\
\text { pengajaran. (poin a } \\
\text { menimbang). Santri } \\
\text { bebas melanjutkan } \\
\text { Pendidikan/ kerja } \\
\text { sesuai dengan } \\
\text { kecendrungan masing- } \\
\text { masing (pasal 19-24). } \\
\text { Kebebasan adalah bebas } \\
\text { dalam memilih alternatif } \\
\text { jalan hidup/ } \\
\text { menentukan masa } \\
\text { depan dengan jiwa besar } \\
\text { / sikap optimistis } \\
\text { menghadapi segala } \\
\text { problematika hidup } \\
\text { berdasarkan nilai Islam } \\
\text { (Tafsir pasal 6). } \\
\text { Diperkuat UU No 35 } \\
\text { Tahun 2014 BAB XIA } \\
\text { tentang perlinduang } \\
\text { anak. } \\
\text { Kitab kuning/ dirasah } \\
\text { islamiah disusun } \\
\text { dengan kurikulum yang } \\
\text { terstruktur, sistematis, }\end{array}$ \\
\hline
\end{tabular}

79 Butir praktik lama adalah praktik tradional yang terjadi di Pesantren. Simpulan tersebut tidak menjelaskan seluruh fenomena dilapangan. Praktik lama yang tersebut tidak untuk mengeneralisasi seluruh Pesantren di Indoensia. Data tersebut diperoleh dari berbagi sumber dari hasil penelitian, publikasi, jurnal dan buku dari penelitian/karya tulis sebelumnya. 


\begin{tabular}{|c|c|c|}
\hline TEORI & PRAKTIK LAMA79 & PROGRESIVISTIK \\
\hline & & $\begin{array}{l}\text { terorganisir, integratif. } \\
\text { (pasal 1, 13). Pesantren } \\
\text { dapat juga } \\
\text { mengintegrasikan } \\
\text { dengan Pendidikan } \\
\text { umum (pasal 5). Kyai } \\
\text { dipersyaratkan lulusan } \\
\text { Pesantren/ perguruan } \\
\text { tinggi Islam/ memiliki } \\
\text { kompetensi agama yang } \\
\text { mumpuni. Pendidikan } \\
\text { dan pengelola Pesantren } \\
\text { harus berkompeten } \\
\text { (pasal 9). } \\
\text { 3. Kyai sebagai teladan, } \\
\text { figur dan pengasuh. } \\
\text { Pembelajaran dituntut } \\
\text { menggunakan berbagai } \\
\text { metode pembelajaran } \\
\text { kreatif. (pasal 13) } \\
\text { 4. Ruanglikup Pesantren } \\
\text { meliputi, Pendidikan, } \\
\text { dakwah dan } \\
\text { pemberdayaan } \\
\text { masyarakat (pasal 4). } \\
\text { Santri diarahakan } \\
\text { melalui Pendidikan } \\
\text { berbasis pengalaman/ } \\
\text { pembiasaan sebagai } \\
\text { tujuan membentuk } \\
\text { karakter. (pasal 10) } \\
\text { Pemerintah } \\
\text { menyiapakan dana } \\
\text { abadi (pasal 49) }\end{array}$ \\
\hline
\end{tabular}

\section{KESIMPULAN DAN SARAN}

Secara filosofis, nilai-nilai yang ingin dicapai atas keabsahan UU Pesantren adalah nilai ontologis, epistemologis dan axiologis. Nilai tersebut terdapat dalam dua tujuan utama penyelenggaraan Pesantren yaitu tujuan Agama dan tujuan 
Rz. Ricky Satria Wiranata : Progresivisme: Titik Temu Keabsahan UU Pesantren Nomor 18 Tahun 2019

Bangsa. Tujuan Agama yaitu membentuk individu yang ahli dalam ilmu agama, beriman, bertakwa, berakhlak mulia, berilmu, mandiri, ta'awun, tawazun, dan tawasut. Sedangkan tujuan Bangsa yaitu terbentuknya pemahaman keberagamaan yang moderat, cinta tanah air, kerukunan hidup umat beragama, serta terbentuk watak peradaban bangsa yang mencerdaskan, bermartabat, dan berkemajuan. Munculnya UU Pesantren ini bertujuan untuk merespon enam isu Pesantren yaitu regulasi, dana abadi, manajamen, Kyai berPendidikan, pembelajaran dan mutu Pesantren.

Berdasarkan analisis progresivisme atas UU Pesantren maka dapat disumpulkan bahwa UU Pesantren berorientasi kepada progresivistik. Butir-butir UU Pesantren sejalan dengan kehendak/ prinsip Pendidikan progresivisme yaang ditawarkan ahli yaitu Pendidikan berbasis pada perkembangan alami anak, Pendidikan harus melahirkan sikap kritis, rasional, empiris. Guru sebagai fasilitator dan sekolah menjadi laboratorium Pendidikan berbasis progresivistik. Selain itu, progresivisme lahir untuk membunuh sikap otoritarianisme yang kerap terjadi dalam sistem Pendidikan di Pesantren. Semua hal tersebut sejalan dengan keabsahan UU Pesantren nomor 18 tahun 2019. 


\section{DAFTAR PUSTAKA}

Departemen Agama RI., 1984/1985. Nama dan Data Potensi PondokPondok Pesantren Seluruh Indonesia. Jakarta: Depag RI.

Fadhillah, M, 2017. Aliran Progresifisme dalam Pendidikan di Indoensia. Jurnal Dimensi: Vol 5, No 1.

Mualifah, Ilun, 2013. Progresivisme John Dewey dan Pendidikan Partisifatif Persfektif Pendidikan Islam, Jurnal Pendidikan Agama Islam, Vol 1, No 1.

Nanuru, Ricardo F., 2013. Progresisvisme Pendidikan dan Relevansinya di Indonesaia, Jurnal Uniera, Vol 2 No 2.

Naskah Akademik, 2018. RUU Tentang Pesantren dan Pendidikan Keagaman, Badan Legislasi.

Nursikin, Mukh, 2016. Aliran-aliran Filsafat Pendidikan dan Implementasinya dalam Pengembangan Kurikulum Pendidikan Islam, Jurnal Attarbiyah, Vol 1 No 2.

O’Dea, Thomas, 1987. Sosiology of Region, Terj. Jakarta: Rajawali.

Saridjo, Marwan, 1982. Sejarah Pondok Pesantren di Indonesia, Jakarta: Dharma Bhakti.

Syukur, Fatah. Dinamika Pesantren dan Madrasah, Yogyakarta: Pustaka Pelajar.

UU Pesantren No 18 Tahun 2019

Yahya, Fata Asyrofi, 2015. Problem Manajemen Pesantren, Sekolah, Madrasah: Problem Mutu dan Kualitas Input-proses-output, Jurnal el-Tarbawi, Vol 8 No 1.

www.kamusperibahasan.com 